\title{
Atmospheric aerosol formation and its growth during the cold season in India
}

\author{
D M Chate* and P Murugavel \\ Indian Institute of Tropical Meteorology, Pune 411 008, India. \\ *e-mail: chate@tropmet.res.in
}

The effects of molecular diffusivity of $\mathrm{H}_{2} \mathrm{SO}_{4}$ and $\mathrm{NH}_{3}$ vapours on nucleated particles of $\mathrm{SO}_{4}^{2-}$ and $\mathrm{NO}_{3}^{-}$species are reported. Condensation sink and source rate of $\mathrm{H}_{2} \mathrm{SO}_{4}$ and $\mathrm{NH}_{3}$ vapours, growth rates and ratios of real to apparent nucleation rates are calculated for $\mathrm{SO}_{4}^{2-}$ and $\mathrm{NO}_{3}^{-}$aerosols using fractional contributions of them in total aerosol size-distribution during the measurement period at Pune, reported in Chate and Pranesha (2004). The percentage of nucleated $\mathrm{SO}_{4}^{2-}$ and $\mathrm{NO}_{3}^{-}$aerosols of mid-point diameter $13 \mathrm{~nm}$ are $2 \%$ and $3 \%$ respectively of the total particles $(13 \mathrm{~nm}$ $\left.\leq D_{p} \leq 750 \mathrm{~nm}\right)$ for both $\mathrm{H}_{2} \mathrm{SO}_{4}$ and $\mathrm{NH}_{3}$ diffusion. In the diameter range $75 \mathrm{~nm} \leq D_{p} \leq 133 \mathrm{~nm}$, it is $48 \%$ and $45 \%$ of $\mathrm{SO}_{4}^{2-}$ and $\mathrm{NO}_{3}^{-}$aerosols, respectively for $\mathrm{NH}_{3}$ diffusion and $43 \%$ and $36 \%$ of $\mathrm{SO}_{4}^{2-}$ and $\mathrm{NO}_{3}^{-}$for $\mathrm{H}_{2} \mathrm{SO}_{4}$ diffusion. Increase in percentage of nucleated particles of these species corresponding to mid-point diameter $133 \mathrm{~nm}$ around $0900 \mathrm{~h}$ IST is significantly higher than that of mid-point diameter $13 \mathrm{~nm}$ and it is due to photo-chemical nucleation, coagulation and coalescence among nucleated clusters. The ratios of real to apparent formation rates for $\mathrm{SO}_{4}^{2-}$ and $\mathrm{NO}_{3}^{-}$aerosols are $12 \%$ and $11 \%$ respectively, corresponding to mid-point diameter $13 \mathrm{~nm}, 17 \%$ and $13 \%$, for midpoint diameter $133 \mathrm{~nm}$ and $12 \%$ and $9.5 \%$, for mid-point diameter $750 \mathrm{~nm}$. The results indicate that nucleation involving $\mathrm{H}_{2} \mathrm{SO}_{4}$ and acidic $\mathrm{NH}_{3}$ diffusion on $\mathrm{SO}_{4}^{2-}$ and $\mathrm{NO}_{3}^{-}$particles is the most relevant mechanism in this region.

\section{Introduction}

Atmospheric new particle formation processes contribute significantly to the global aerosol distributions (Spracklen et al 2006). A review of literature compiled about 100 papers reports observations of 'aerosol nucleation' throughout the troposphere (Kulmala et al 2004). Nucleation from the gaseous precursors leads to the formation of nucleated particles in the diameter range $3 \mathrm{~nm} \leq D_{p} \leq 20 \mathrm{~nm}$. Precursors such as $\mathrm{SO}_{2}, \mathrm{NO}_{2}$ and organic compounds are emitted mostly from combustion sources. Increased concentrations of $\mathrm{O}_{3}, \mathrm{SO}_{2}, \mathrm{NO}_{2}$ and organic compounds can influence the conversion of Volatile Organic Compounds (VOC) into condensable vapours to form nucleated clusters and these clusters grow to particles through condensation of organic and inorganic vapours. Freshly nucleated particles typically grow to 10 to $100 \mathrm{~nm}$ at rates of 1 to $20 \mathrm{~nm} \mathrm{~h}^{-1}$ during the course of a day (Kulmala et al 2004). Further growth of nucleated particles takes place by diffusion of vapour molecules (Seinfeld and Pandis 1998). Various nucleation mechanisms are found in the literature involving water and sulphuric acid (Vehkamäki et al 2002), water-sulphuric acidammonia (Merikanto et al 2007), ion-induced nucleation (Modgil et al 2005), ion induced and sulfate aerosols (Kazil and Lovejoy 2007), and sulphuric-acid vapour (Riipinen et al 2007; Kuang et al 2008). However, specifying the most relevant nucleation mechanism for new particle formations in various environments is a challenging task.

Keywords. Nucleation; coagulation; condensation; photo-chemistry; gaseous precursors. 
In India, formation and growth rates of particles were estimated from the measured aerosol size distributions at Delhi (Mönkkönen et al 2005). But it is difficult to classify the newly formed and the pre-existing particles when background aerosol concentrations are higher (Alam et al 2003). Chate and Devara (2005) have estimated nucleation and growth rates of aerosols using measured aerosol size distributions reported in Chate and Pranesha (2004) at a relatively less polluted environmental site, Pune. Particle size distributions were measured with an Electrical Aerosol Analyzer (EAA Model 3030, TSI Inc.) which covers 10 size ranges of $3.2-5.6,5.6-$ $10,10-17.8,17.8-31.6,31.6-56.2$, 56.2-100, 100$178,178-316,316-562$ and $562-1000 \mathrm{~nm}$ and gives the number concentration against mid-point diameters which are the logarithmic centre of these size ranges. Recently, Murugavel and Chate (2009) have reported the formation and growth rates of particles from the size distributions of aerosols in the diameter range $20 \mathrm{~nm} \leq D_{p} \leq 600 \mathrm{~nm}$ measured at this site using Scanning Mobility Particle Sizer (Model 3936, TSI, USA). To the authors' knowledge no attempt has been made to study the chemistry of the associated particles and condensing vapours involved in photo-chemically driven nucleation and growth of nucleated particles over Indian region.

Nucleation bursts start producing molecular clusters which are of very small diameter below $1 \mathrm{~nm}$ and then they grow to diameter which can be detected by the measurement systems. Nucleated particles start to be observed only if the clusters grow to the detectable equivalent diameter of the aerosol analyzers (aerodynamic and stokes diameter, optical equivalent, electrical mobility equivalent and diffusion equivalent diameters), which means that they have already grown for some time starting from their initial diameter. Aerosol nucleation strongly depends on concentrations of sulphuric acid and other condensable vapours $\left(\mathrm{H}_{2} \mathrm{O}\right.$ and acidic $\left.\mathrm{NH}_{3}\right)$ of low volatility. Solar radiation, atmospheric mixing processes, levels of precursors and chemistry of aerosols affect the nucleation processes. The elapsed-time evolutions of poly-dispersed aerosols of individual chemical compounds during nucleation bursts are difficult to measure using aerosol analyzers.

The diffusion of molecules of condensable vapours to the surface of nucleated clusters results in the growth of nucleated particles of various compounds. Determination of the formation and growth rates when molecules of various condensable vapours diffuse on freshly produced particles of major species is important to understand the nucleation processes. The concentration of vapours $\left(\mathrm{H}_{2} \mathrm{O}\right.$, acidic $\mathrm{NH}_{3}, \mathrm{H}_{2} \mathrm{SO}_{4}$, etc. $)$ and its source rate for particles of major species and diameters are likely to be of interest to modellers who deal with the physico-chemical properties of aerosols. Apparent nucleation rates and real formation rates calculated from the measured aerosol sizedistribution are also important for extractions of the number concentrations of nucleated particles of major species before they grow to detectable diameters. Nucleated clusters are initially of $1 \mathrm{~nm}$ in diameter and as they are too small to be detected by aerosol analyzers, one actually measures the apparent formation rates at which aerosols appear at detectable diameters instead of real ones. For estimations of real nucleation rates and number of nucleated aerosols of major species, an alternative is to rely on the assumption of number concentrations of particles of major species distributed in total aerosols. We report the effects of molecular diffusivity of $\mathrm{H}_{2} \mathrm{SO}_{4}$ and $\mathrm{NH}_{3}$ vapours on nucleated $\mathrm{SO}_{4}^{2-}$ and $\mathrm{NO}_{3}^{-}$particles. We present the concentrations of freshly produced nucleated particles of sulfates and nitrates, their nucleation rates and growth properties from the analysis of aerosol size distributions measured in the field experiments of Chate and Pranesha (2004). The details of instruments used for the measurement of chemical compounds are found in Momin et al (1999).

\section{Methodology}

The Knudsen numbers $\left(K_{n}\right)$, transitional correction factors $\left(\beta_{m}\right)$ for the condensational mass flux of vapour concentrations $(C)$ and factors $\gamma$ as a function of particle size distributions are taken from Chate and Devara (2005). Condensation sink $(C S)$ depends on the diameter of the particles and is a measure of the rate by which the vapour condenses onto the whole particle population and also it determines how rapidly vapour molecules will condense onto pre-existing aerosols. The growth rate $(G R), C S$ and source rates $(Q)$ of condensing vapours are derived as below.

Diffusion coefficient for condensing vapours in air for temperatures between -40 and $40^{\circ} \mathrm{C}$ (Pruppacher and Klett 2000) as a function of temperature and pressure is expressed as:

$$
D_{v}(T, P)=D_{v}(0,1)\left(\frac{T}{T_{0}}\right)^{1.94}\left(\frac{P_{0}}{P}\right)
$$

where $D_{v}(0,1)$ is the diffusion coefficient of gaseous species at STP with $T_{0}=273.15 \mathrm{~K}, P_{0}=1023.25 \mathrm{mb}$, $T=293.15 \mathrm{~K}, P=950 \mathrm{mb}$ and $D_{v}$ in $\mathrm{cm}^{2} \mathrm{~s}^{-1}$. Molecular diffusivities or diffusion coefficients are adopted from Massman (1998). 
Assuming growth of particles at constant rate by condensation, the GR is expressed as (Kulmala et al 1998a, 2004):

$$
\frac{d D_{p}}{d t}=\frac{4 m_{v} \beta_{m} D_{v} C}{D_{p} \rho_{p}}
$$

where $m_{v}$ is the molecular mass of condensable vapour, $C$ is responsible for the growth of newly formed particles, and $\rho_{p}$ is the density of aerosol particle. Equation (2) can be integrated from $D_{p 0}$ to $D_{p}$ for $C$ (Kulmala et al 2001a, 2004) as:

$$
\begin{aligned}
C= & \frac{\rho_{p}}{\Delta t D_{v} m_{v}}\left\{\left(\frac{D_{p}^{2}-D_{p 0}^{2}}{8}\right)+\frac{\lambda\left(D_{p}-D_{p 0}\right)}{2}\right. \\
& \left.\times\left(\frac{4}{3 \alpha}-0.623\right)+0.623 \lambda^{2} \ln \frac{\left(2 \lambda+D_{p}\right)}{\left(2 \lambda+D_{p 0}\right)}\right\} .
\end{aligned}
$$

Here $\alpha$ is assumed to be unity and $\Delta t$ is the time difference between formation of new particles and their growth from initial diameter $D_{p 0}$ to larger $D_{p}$.

$C S$ depends on molecular diffusivities, aerosol size and distribution functions of different species (Pirjola et al 1999, 2002; Kulmala et al 2001b, 2004),

$$
C S=2 \pi D_{v} \int_{0}^{\infty} D_{p} \beta_{m} N\left(D_{p}\right) d D_{p}
$$

where $N\left(D_{p}\right)$ is fractional size distribution of particles of various species in total aerosols.

Assuming vapour molecules of $\mathrm{H}_{2} \mathrm{O}, \mathrm{H}_{2} \mathrm{SO}_{4}$ and acidic $\mathrm{NH}_{3}$ diffuses to the surface of the nucleated particles, the time dependence of the vapour concentration can be expressed as (Kulmala et al 1998b; Kerminen et al 2004):

$$
\frac{d C}{d t}=Q-C S \cdot C
$$

Assuming a steady state vapour concentration, the source rate $Q$ can be estimated from:

$$
Q=C S \cdot C
$$

Parameter $\eta$ is a measure of the number concentrations of nucleated particles and function of $C S$ at $\alpha=1$ and GR (Kerminen and Kulmala 2002)

$$
\eta=\frac{\gamma C S_{\alpha=1}^{\prime}}{G R}
$$

where

$$
C S_{\alpha=1}^{\prime}=\sum_{i} 0.5 D_{p, j} \beta_{m} N\left(D_{p}\right)
$$

Chate and Pranesha (2004) measured the distributions of particles of mid-point diameter $\geq 13 \mathrm{~nm}$. Number concentrations of newly formed particles corresponding to already grown sizes,

$$
N\left(D_{\text {nuc,ini }}\right)=\frac{N\left(D_{p}\right)}{\exp \left(\eta / D_{p}-\eta / D_{\text {nuc,ini }}\right)}
$$

where $N\left(D_{p}\right)$ is the measured aerosol number concentrations, $D_{\text {nuc,ini }}$ is the initial size of nucleated clusters. Real formation rate (Kerminen and Kulmala 2002) prior to the growth of newly formed nucleated particles is written as:

$$
J(t)_{\text {real }}=\frac{N\left(D_{\text {nuc,ini }}\right)}{\Delta t} .
$$

Apparent formation rate is related to the real formation rate corresponding to the number of new particles as (Kerminen and Kulmala 2002):

$$
J(t)_{\text {apparent }}=J(t)_{\text {real }} \exp \left[\eta / D_{p}-\eta / D_{\text {nuc,ini }}\right] .
$$

\section{Results}

It has been observed by Momin et al (1999) at IITM, Pune site that total fine size particles were fractionally distributed in the form of:

- water soluble particles including those produced from gas-to-particle conversions (30\%),

- conversions of VOCs (40\%), and

- particles emitted from the combustion sources $(30 \%)$ as shown in figure 1.

We have assumed these fractional distributions for water soluble $\left(\mathrm{SO}_{4}\right.$ and $\left.\mathrm{NO}_{3}\right)$ fine mode particles $\left(D_{p} \leq 1000 \mathrm{~nm}\right.$ ) (figure 1) and used with the aerosol size-distribution data reported in Chate and Pranesha (2004) to investigate the effects of $\mathrm{H}_{2} \mathrm{SO}_{4}$ and acidic $\mathrm{NH}_{3}$ vapours on formation and growth of nucleated aerosols in this study, because to date, no data are available on size-distributions of aerosols of various species at this site.

From the diurnal variation of aerosol size distributions reported in Chate and Pranesha (2004), the baseline distributions at $0300 \mathrm{~h}$ IST (corresponding to $82.5^{\circ} \mathrm{E}$ longitude), depleted number distributions owing to fog formation at $0600 \mathrm{~h}$ IST and enhanced number distributions of total 


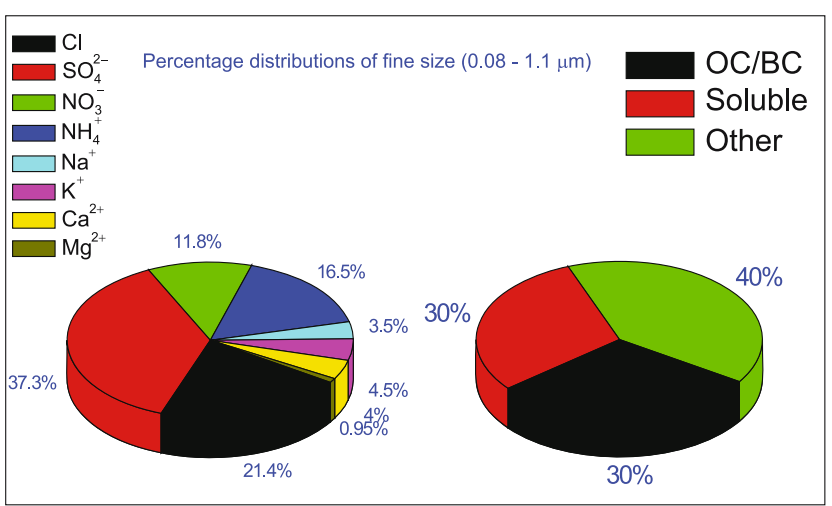

Figure 1. Percentage distributions of aerosols of various species in fine size particles in total distributions at Pune, India (Momin et al 1999).

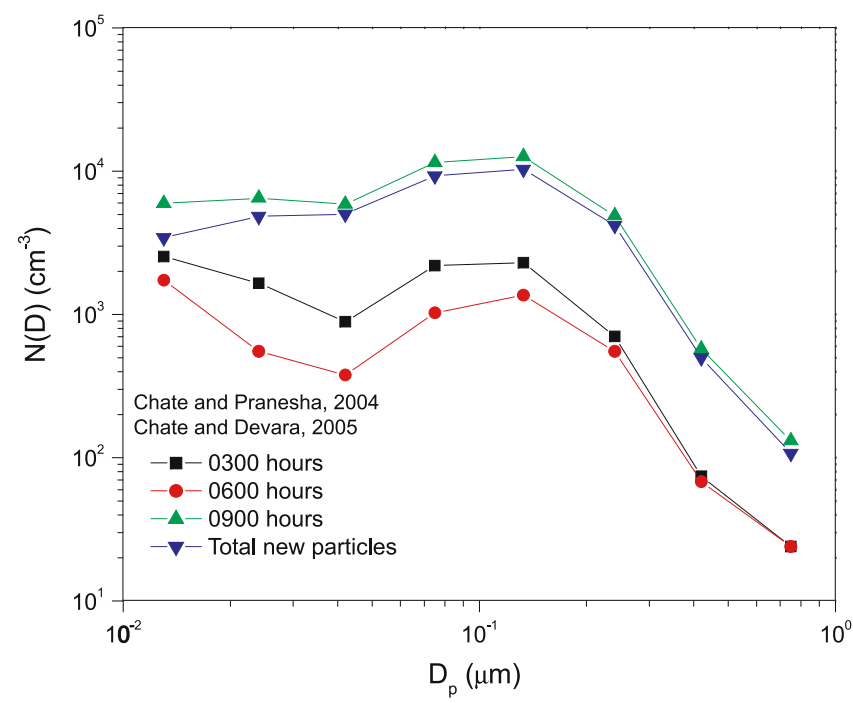

Figure 2. Particle size distributions at 0300, 0600 and $0900 \mathrm{~h}$ IST and the total new particles during cold season at Pune (estimated from measurements of Chate and Pranesha 2004).

nucleated particles around $0900 \mathrm{~h}$ IST are estimated and plotted in figure 2. The Earth's surface layer starts cooling at about $0300 \mathrm{~h}$ IST and continues to cool till morning $0600 \mathrm{~h}$ IST. Due to moisture contents in the cold air, fraction of hygroscopic particles present in the measured distributions at $0300 \mathrm{~h}$ IST start serving as nuclei for fog droplets. As a result, number-size distributions of total particles around $0600-0700 \mathrm{~h}$ IST are less than those observed at $0300-0600 \mathrm{~h}$ IST. Photo-chemically driven nucleation could occur only after the sunrise and produces many folds of fresh particles around 0800-0900 h IST. The growth of freshly produced particles takes place mainly through condensation of vapours $\left(\mathrm{H}_{2} \mathrm{SO}_{4}\right.$, acidic $\mathrm{NH}_{3}$, etc.), coagulation and coalescence among nucleated clusters. Particles released through evaporation of fog droplets after sunrise

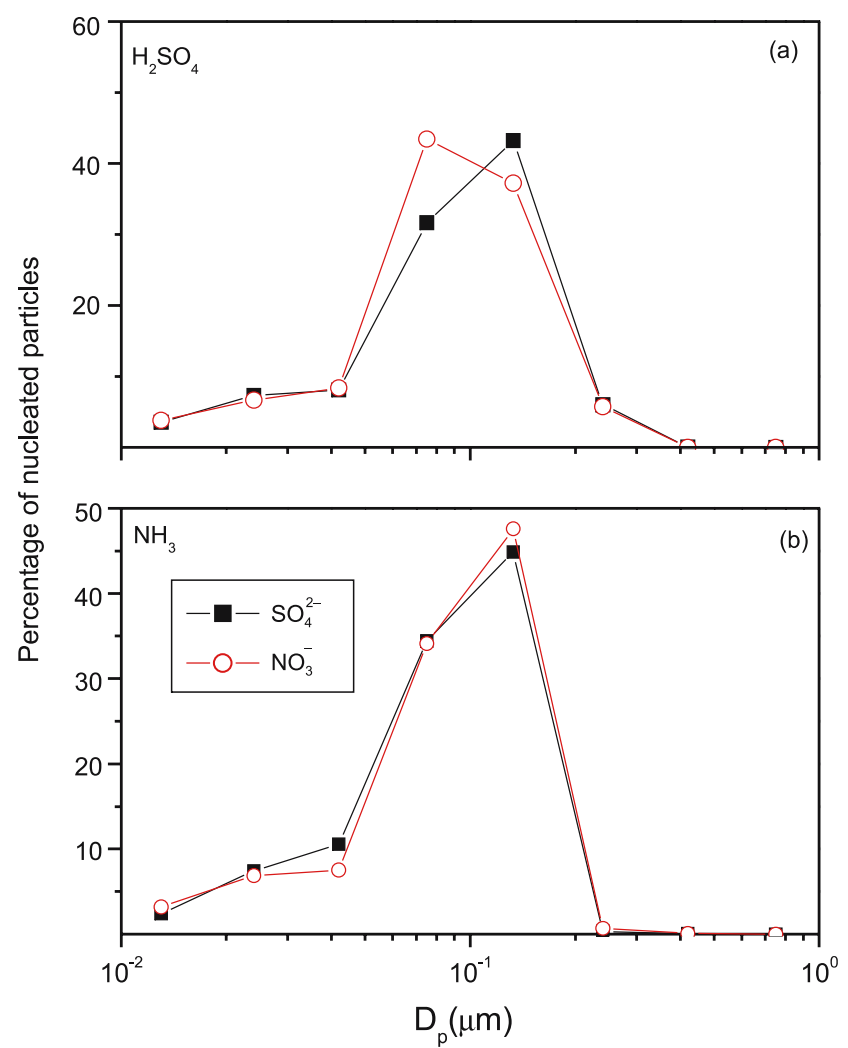

Figure 3. Percentage of $\mathrm{SO}_{4}$ and $\mathrm{NO}_{3}$ particles with size for $\mathrm{H}_{2} \mathrm{SO}_{4}$ and acidic $\mathrm{NH}_{3}$ diffusions.

superimpose on photo-chemically formed particles which have already grown to detectable size of measuring system. Therefore, measured particle number-size distributions around $0900 \mathrm{~h}$ IST (starting point of atmospheric mixing processes) shows a sharp increase in number concentration. The difference between size-distributions at $0900 \mathrm{~h}$ IST and distributions at $0300 \mathrm{~h}$ IST is corresponding to freshly formed particles as shown in figure 2 . This excess concentration of particles in the size range $13 \mathrm{~nm} \leq D_{p} \leq 750 \mathrm{~nm}$ suggests that nucleation is photo-chemically driven and condensation, coagulation and coalescence processes are responsible for the growth of these particles.

It is desirable to quantify the influence of molecular mass and diffusivity of vapours of different species on formation rate and growth properties of nucleated aerosols. Percentages of number concentration of $\mathrm{SO}_{4}^{2-}$ and $\mathrm{NO}_{3}^{-}$aerosols formed through condensation of $\mathrm{H}_{2} \mathrm{SO}_{4}$ and acidic $\mathrm{NH}_{3}$ are illustrated in figure 3 . At the mid-point diameter $13 \mathrm{~nm}$, the percentages of freshly produced and already grown $\mathrm{SO}_{4}^{2-}$ and $\mathrm{NO}_{3}^{-}$aerosols are 2 and $3 \%$ respectively of the total particles $\left(13 \mathrm{~nm} \leq D_{p} \leq 750 \mathrm{~nm}\right)$ for both $\mathrm{H}_{2} \mathrm{SO}_{4}$ and acidic $\mathrm{NH}_{3}$ diffusions. Whereas in the mid-point diameter range $75 \mathrm{~nm} \leq D_{p} \leq 133 \mathrm{~nm}$, it is $48 \%$ of $\mathrm{SO}_{4}^{2-}$ and $45 \%$ of $\mathrm{NO}_{3}^{-}$aerosols for acidic $\mathrm{NH}_{3}$ 


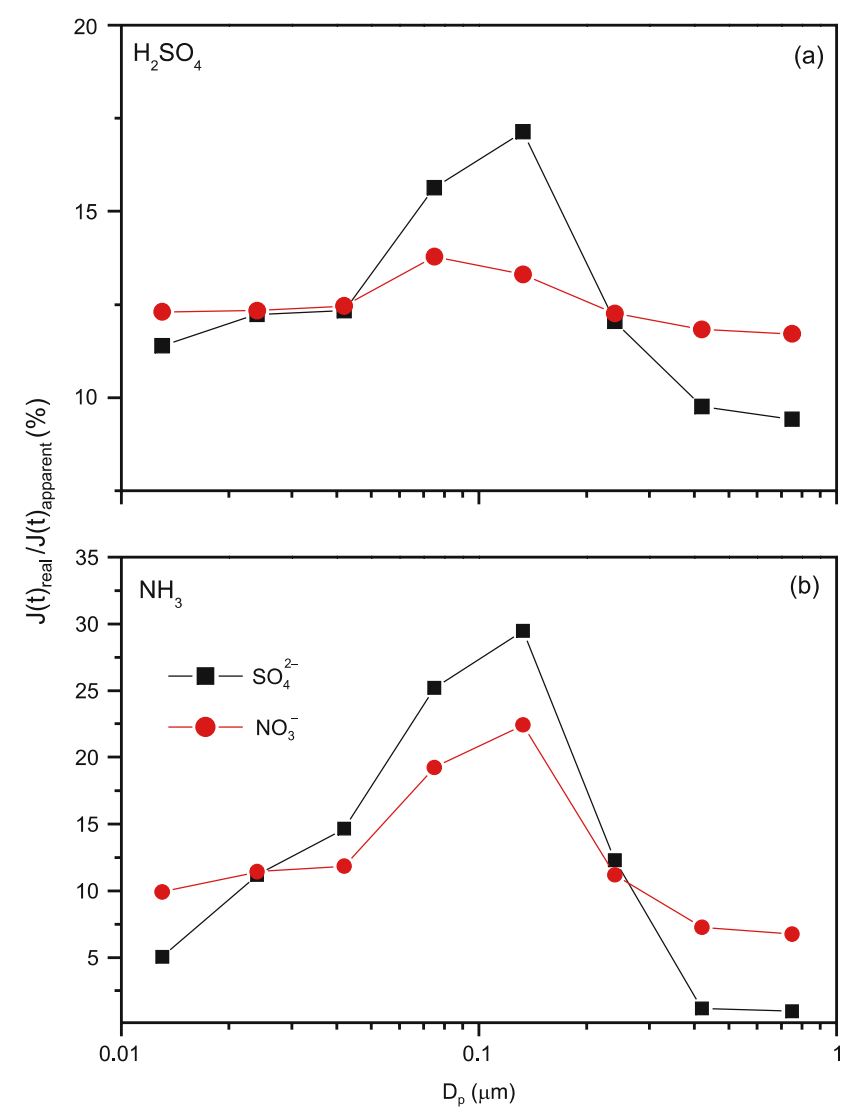

Figure 4. Percentage ratios of real to apparent nucleation rate for $\mathrm{SO}_{4}$ and $\mathrm{NO}_{3}$ particles with size for $\mathrm{H}_{2} \mathrm{SO}_{4}$ and acidic $\mathrm{NH}_{3}$ diffusions.

diffusion and $43 \%$ of $\mathrm{SO}_{4}^{2-}$ and $36 \%$ of $\mathrm{NO}_{3}^{-}$for $\mathrm{H}_{2} \mathrm{SO}_{4}$ diffusion (figure 3). The particles in this diameter range are found in the atmosphere generally due to vehicular emissions in urban environments (Zhu et al 2002). However, wind speed was almost zero during early morning to $0900 \mathrm{~h}$ IST and hence advection of ultrafine particles emitted from the vehicular emission in this diameter range to the point of measurement is a remote possibility. This feature for particles of mid-point diameter $133 \mathrm{~nm}$ is in agreement with our previous results (Chate and Devara 2005). The strong interplay between the nuclei growth and their loss by coagulation may be responsible for the higher percentage of $75 \mathrm{~nm} \leq D_{p} \leq 133 \mathrm{~nm}$ particles. Photo-chemically driven nucleation by solar radiation, coagulation of nuclei onto pre-existing particles and also coalescence among freshly produced nucleated clusters resulted into major share of $75 \mathrm{~nm} \leq D_{p} \leq 133 \mathrm{~nm}$ particles. Further observations including solar radiation would provide the insight into quantitative strengths of photo-chemical nucleation relative to coagulation.

The apparent nucleation rates, real number concentrations of newly formed $\mathrm{SO}_{4}^{2-}$ and $\mathrm{NO}_{3}^{-}$ particles are computed based on the percentages of chemical species given in figure 1 , for the measured particle size distributions from the equation (2) to equation (11). In figure 4, the variation in percentage ratios of real to apparent formation rates for $\mathrm{SO}_{4}^{2-}$ and $\mathrm{NO}_{3}^{-}$particles are shown as a function of diameter. The ratios of real to apparent formation rates $\left(\mathrm{J}(\mathrm{t})_{\text {real }} / \mathrm{J}(\mathrm{t})_{\text {apparent }}(\%)\right)$ for $\mathrm{SO}_{4}^{2-}$ and $\mathrm{NO}_{3}^{-}$ aerosols for $\mathrm{H}_{2} \mathrm{SO}_{4}$ diffusion are $12 \%$ and $11 \%$ corresponding to mid-point diameter $13 \mathrm{~nm}, 17 \%$ and $13 \%$ corresponding to mid-point diameter $133 \mathrm{~nm}$, and $12 \%$ and $9.5 \%$ corresponding to mid-point diameter $750 \mathrm{~nm}$. Similar trends are followed for percentage ratios as a function of $\mathrm{SO}_{4}^{2-}$ and $\mathrm{NO}_{3}^{-}$ particle diameters for $\mathrm{NH}_{3}$ diffusion as shown in figure $4(\mathrm{~b})$. Thus percentage of $\mathrm{J}(\mathrm{t})_{\text {real }} / \mathrm{J}(\mathrm{t})_{\text {apparent }}$ depends on the fractional number concentrations of particles of various chemical species in total nucleated particles and it is a measure of number concentration of freshly produced particles by photo-chemical nucleation. The results indicate that aerosol nucleation mechanism is coupled strongly with chemistry, particularly involving $\mathrm{H}_{2} \mathrm{SO}_{4}$ and acidic $\mathrm{NH}_{3}$ diffusion on freshly nucleated particles of $\mathrm{SO}_{4}^{2-}$ and $\mathrm{NO}_{3}^{-}$at semi-urban environment (Pune, India).

Despite the importance of photo-chemical nucleation and growth properties of nucleated aerosols of various compositions over this location, some comparison with the published results is desirable. Real formation rates derived in this study are 17 and 79 particles $\mathrm{cm}^{-3} \mathrm{~s}^{-1}$ for $\mathrm{SO}_{4}^{2-}$ and $\mathrm{NO}_{3}^{-}$nucleated particles respectively corresponding to midpoint diameter $13 \mathrm{~nm}$. The formation rate worked out by Kulmala et al (2004) vary between 0.5 and $16 \mathrm{~cm}^{-3} \mathrm{~s}^{-1}$ for $15 \mathrm{~nm}$ particles over subtropic rural desert site, between 1 and $1.5 \mathrm{~cm}^{-3} \mathrm{~s}^{-1}$ for $10 \mathrm{~nm}$ particles over mid-latitude coastal land and between 5 and $40 \mathrm{~cm}^{-3} \mathrm{~s}^{-1}$ over mid-latitude rural land. Nucleation rates as high as $10^{4}$ to $10^{5}$ particles $\mathrm{cm}^{-3} \mathrm{~s}^{-1}$ have been reported for $3 \mathrm{~nm}$ particles in coastal environments and industrial plumes (Kulmala 2003). Growth rates of diameter $3 \mathrm{~nm}$ varied between 11.6 and $16 \mathrm{~nm} \mathrm{~h}^{-1}$ at New Delhi, India (Mönkkönen et al 2005) as against 0.07 to $0.7 \mathrm{~nm} \mathrm{~h}^{-1}$ at Pune for both $\mathrm{NO}_{3}^{-}$and $\mathrm{SO}_{4}^{2-}$ particles corresponding to mid-point diameter $13 \mathrm{~nm}$. Large concentrations of pre-existing/background aerosols with higher levels of condensing vapours at a mega-city (New Delhi) relative to Pune (semiurban) may be responsible for the discrepancy in the formation rate. Other factors responsible for the discrepancy may be large vehicular traffic density, entirely different atmospheric conditions including solar radiation and observational period at New Delhi as compared to clear, calm conditions during measurements at Pune. Measurements of real-time chemical compositions of particle 
size-spectra may be possible in future during nucleation events in tropical region (Douglas et al 2003). One can derive the nucleation coefficients for freshly produced nucleated particles of various species in terms of real and apparent nucleation rates, provided appreciable data of real-time chemical compositions of particle size distributions, levels of various condensing vapours and magnitude of solar radiation are made available.

\section{Conclusions}

The formation rates and growth properties of atmospheric particles by nucleation mechanisms have received much attention of research community in the recent years. The condensation sink and source rates of $\mathrm{H}_{2} \mathrm{SO}_{4}$ and acidic $\mathrm{NH}_{3}$ vapours, growth rate and the ratios of real to apparent formation rates are calculated for $\mathrm{SO}_{4}^{2-}$ and $\mathrm{NO}_{3}^{-}$ particles. The nucleated $\mathrm{SO}_{4}^{2-}$ and $\mathrm{NO}_{3}^{-}$aerosols of mid-point diameter $13 \mathrm{~nm}$ are found $2 \%$ and $3 \%$ of the total particles for $\mathrm{H}_{2} \mathrm{SO}_{4}$ and $\mathrm{NH}_{3}$ diffusions. In the diameter range $75 \mathrm{~nm} \leq D_{p} \leq 133 \mathrm{~nm}$, photo-chemically driven nucleation, coagulation and coalescence of nucleated clusters causes $48 \%$ of $\mathrm{SO}_{4}^{2-}$ and $45 \%$ of $\mathrm{NO}_{3}^{-}$aerosols for $\mathrm{NH}_{3}$ diffusion and $43 \%$ of $\mathrm{SO}_{4}^{2-}$ and $36 \%$ of $\mathrm{NO}_{3}^{-}$for $\mathrm{H}_{2} \mathrm{SO}_{4}$ diffusion. The percentage of $\mathrm{J}(\mathrm{t})_{\text {real }} / \mathrm{J}(\mathrm{t})_{\text {apparent }}$ depends on the fractional concentrations of particles of various species in total nucleated particles and it is a measure of number concentration of freshly produced particles during photo-chemical nucleation. The results presented indicate that nucleation involving $\mathrm{H}_{2} \mathrm{SO}_{4}$ and acidic $\mathrm{NH}_{3}$ diffusion on $\mathrm{SO}_{4}^{2-}$ and $\mathrm{NO}_{3}^{-}$particles is the most important mechanism at Pune, India. The results need support with the real-time measurements of chemical compositions of aerosol size spectra and $\mathrm{H}_{2} \mathrm{SO}_{4}$ and acidic $\mathrm{NH}_{3}$ vapours during nucleation events. Further efforts are warranted to identify the nucleation events in different environments over Indian region to collect appreciable data of chemical compositions of particle size-spectra with meteorological parameters including magnitude of solar radiation, temperatures and humidity. Relative humidity (RH) affects primarily in moisture uptake of hygroscopic nucleated clusters and particles. Pre-existing hygroscopic particles absorb more moisture as RH increases and newly formed particles become a major sink for condensing vapours. However, there are number of practical problems in dealing with the aerosols of various chemical compositions associated to the atmospheric nucleation events. For example, yet the actual nucleation mechanism and the role of chemical constituents remain to be identified.
Future work should include observations of chemical composition of aerosol size distributions in different environments, measurements of gaseous compounds participating in nucleation and growth properties of nucleated particles.

\section{Acknowledgement}

Authors express their gratitude to the Prof. B N Goswami, Director, IITM, Pune for his encouragement.

\section{References}

Alam A, Shi Ping J and Harrison R 2003 Observations of new particle formation in urban air; J. Geophys. Res. 108 D3, doi: 1029/2001/JD001417.

Chate D M and Pranesha T S 2004 Field measurements of sub-micron aerosol concentrations during cold season in India; Curr. Sci. 86/12 1610-1613.

Chate D M and Devara P C S 2005 Growth properties of sub-micron aerosols during cold season in India; Aerosol Air Qual. Res. 5/2 1-14.

Douglas A O, Ma Y, Sullivan A, Sierau B, Baumann K and Weber R J 2003 Refinements to the particle-into-liquid sampler (PILS) for ground and airborne measurements of water soluble aerosol composition; Atmos. Environ. $\mathbf{3 7}$ $1243-1259$.

Kazil J and Lovejoy E R 2007 A semi-analytical method for calculating rates of new sulfate aerosol formation from the gas phase; Atmos. Chem. Phys. 7 3447-3459, http://www.atmos-chem-phys.net/7/3447/2007/.

Kerminen V M and Kulmala M 2002 Analytical formulae connecting the 'real' and 'apparent' nucleation rate and the nucleus number concentration for atmospheric nucleation events; J. Aerosol Sci. 33 609-622.

Kerminen V M, Kari E, Lehtinen J, Anttila $\mathrm{T}$ and Kulmala M 2004 Dynamics of atmospheric nucleation mode particles: A timescale analysis; Tellus $\mathbf{5 6 B}$ 135-146.

Kuang C, McMurry P H, McCormick A V and Eisele F L 2008 Dependence of nucleation rates on sulfuric acid vapor concentration in diverse atmospheric locations; J. Geophys. Res. 113 D10209, doi: 10.1029/2007JD 009253.

Kulmala M, Mäkelä J M, Koponen I and Pirjola L 1998a Formation of cloud condensation nuclei in boreal forest area; J. Aerosol Sci. 29 (suppl. 1) pp. S567-S568.

Kulmala M, Toivonen A, Makela J M and Laaksonen A 1998b Analysis of the growth of nucleation mode particles in Boreal Forest; Tellus 50 449-462.

Kulmala M, Hameri K, Aalto P, Makela J M, Pirjola L, Nilsson E D, Buzorius G, Rannick U, Dal Maso M, Seidl W, Hoffmann T, Janson R, Hansson H C, Viisanen Y, Laaksonen A and O'Dowd C D 2001a Overview of the International Project on biogenic aerosol formation in the boreal forest (BIOFOR); Tellus $\mathbf{5 3 B}$ 324-343.

Kulmala M, Dal Maso M, Makela J M, Pirjola L, Vakeva M M, Aalto P, Mikkulainen P, Hameri K and O'Dowd C D 2001b On the formation, growth and composition of nucleation mode particles; Tellus 53B 479-490.

Kulmala M 2003 How particles Nucleate and Grow?; Science 302 1000-1001. 
Kulmala M, Vehkamki H, Petaja T, Dal Maso M, Lauri A, Kerminen V M, Birmili W and McMurry P 2004 Formation and growth rates of ultra fine atmospheric particles a review of observations; J. Aerosol Sci. 35 143-176.

Massman W J 1998 A review of the molecular diffusivities of $\mathrm{H}_{2} \mathrm{O}, \mathrm{CO}_{2}, \mathrm{O}_{3}, \mathrm{SO}_{2}, \mathrm{NH}_{3}, \mathrm{~N}_{2} \mathrm{O}, \mathrm{NO}$, and $\mathrm{NO}_{2}$ in air, $\mathrm{O}_{2}$ and $\mathrm{N}_{2}$ near STP; Atmos. Environ. 32 1111-1127.

Merikanto J, Napari I, Vehkamäki H, Anttila T and Kulmala M 2007 New parameterization of sulphuric acid-ammonia water ternary nucleation rates at tropospheric conditions; J. Geophys. Res. 11 D15207, doi:10.1029/2006JD007977.

Modgil M S, Kumar S, Tripathi S N and Lovejoy E R 2005 A parameterization of ion-induced nucleation of sulphuric acid and water for atmospheric conditions; J. Geophys. Res. 110 D19205, doi: 10.1029/2004JD005475.

Momin G A, Rao P S P, Safai P D, Ali K, Naik M S and Pillai A G 1999 Atmospheric aerosol characteristics studies at Pune and Thiruvananthapuram during INDOEX-1998; Curr. Sci. 76 985-989.

Mönkkönen P, Koponen I K, Lehtinen K E J, Hämeri K, Uma R and Kulmala M 2005 Measurements in a highly polluted Asian mega city: Observations of aerosol number size distribution, modal parameters and nucleation events; Atmos. Chem. Phys. 5 57-66.

Murugavel P and Chate D M 2009 Generation and growth of aerosols over Pune, India; Atmos. Environ. 43 820-828.

Pirjola L, Kulmala M, Wilck M, Bischoff A, Stratmann F and Otto E 1999 Effects of aerosol dynamics on the formation of sulfuric acid aerosols and cloud condensation nuclei; J. Aerosol Sci. 30 1079-1094.
Pirjola L, Korhonen H and Kulmala M 2002 Condensation/evaporation of insoluble organic vapor as functions of source rate and saturation vapor pressure; J. Geophys. Res. 107(D11) 4108, doi: 10.1029/2001JD001228.

Pruppacher H R and Klett J D 2000 Microphysics of clouds and precipitation (London: Kluwer Academic Publishers), pp. 954.

Riipinen I, Sihto S L, Kulmala M, Arnold F, Dal Maso M, Birmili W, Saarnio K, Teinil K, Kerminen V M, Laaksonen A and Lehtinen K E J 2007 Connections between atmospheric sulphuric acid and new particle formation during QUEST IIIIV campaigns in Heidelberg and Hyytiälä; Atmos. Chem. Phys. 7 1899-1914.

Seinfeld J H and Pandis S N 1998 Atmospheric Chemistry and Physics; A Wiley Interscience Publication (New York: John Wiley \& Sons, Inc), pp. 1326.

Spracklen D V, Carslaw K S, Kulmala M, Kerminen V M, Mann G W and Sihto S L 2006 The contribution of boundary layer nucleation events to total particle concentrations on regional and global scales; Atmos. Chem. Phys. 6 5631-5648, http://www.atmos-chemphys.net/6/5631/2006/.

Vehkamäki H, Kulmala M, Napari I, Lehtinen K E J, Timmreck C, Noppel M and Laaksonen A 2002 An improved parameterization for sulphuric acid-water nucleation rates for tropospheric and stratospheric conditions; J. Geophys. Res. 107(D22) 4622, doi: 10.1029/2002JD2184.

Zhu Y, Hinds W C, Kim S, Shen S and Sioutas C 2002 Study of ultra fine particles near a major highway with heavy-duty diesel traffic; Atmos. Environ. 36 4323-4335. 